\title{
Groundwater Studies of Sunshine Garden Estate, Oba-Ile Akure Southwestern Nigeria using Electromagnetic Method
}

\author{
Toluwaleke Ajayi ${ }^{1}$, Rereloluwa Bello ${ }^{1}$, Otitoloju Matthew ${ }^{2}$ \\ Department of Earth Sciences, Crawford University, Ogun State, Nigeria ${ }^{1}$ \\ Department of Geology, University of Porthacourt, Rivers State, Nigeria ${ }^{2}$
}

\begin{abstract}
The electromagnetic profiling in the Sunshine Garden Estate, Oba-Ile has contributed to a better understanding of the basement complex terrain of Southwestern Nigeria. The use of Electromagnetic profiling for both water quality evaluations and groundwater resource mapping has increased significantly over the years. The EM profiling has proved very common with groundwater investigation because it helps to identify subsurface structures yielding groundwater and also helps in delineating groundwater contaminated zone The result shows values of the filtered imaginary vary from -35.1 to 64.8 while that of the raw real ranges from -19 to 35.1 across the study area. The profiles for the EM sections contain small filtered anomaly in the imaginary part and significant maxima in the real part. Zones with peak positive filtered real anomalies are considered priority areas for groundwater development in the study area since its correlates with zones of high conductivity which is a characteristic of water filled faults or fractures Sites with high electromagnetic anomaly (high positive filtered real anomaly) as shown in the EM profile can be expected to be aquifers, implying locations suitable for the groundwater development in the study area
\end{abstract}

Keywords: Electromagnetic profiling, Basement complex, Groundwater, Groundwater Development, Conductivity, Anomaly.

\section{INTRODUCTION}

Electromagnetic (EM) profiling are widely used geophysical technique in the location of fissured media and delineation of basement regolith [1]-[4]. On so many occasions, reconnaissance EM surveys are used to identify aquiferous zones such as joints, faults and fractures which can greatly help in locating productive water wells in crystalline basement rock terrains [5]-[6].

Groundwater accounts for about $93 \%$ of the water required for consumption. It also provides a significant constant supply, in contrast to the case of surface water which can be easily polluted or susceptible to dryness, Groundwater can be found beneath the subsurface, contained in Fractures, Faults, Porous and permeable formations. Groundwater is extracted from these geological structures through wells or boreholes

The use of Electromagnetic profiling for both water quality evaluations and groundwater resource mapping has increased significantly over the years. The EM profiling has proved very common with groundwater investigation because it helps to identify subsurface structures yielding groundwater and also helps in delineating groundwater contaminated zone

As a result of large industrial and agricultural activities and continuous increase in population growth, there has been large demand for potable water within Akure and its environs. There is also inadequate water supply at sunshine estate. This is because the water from borehole, hand dug wells and stream in sunshine estate can no longer serve its commercial needs due to high water consumption. This has resulted to proper geophysical investigation to be conducted in the area in order to delineating geological structures such as fault and fractures revealing aquiferous zone. The aim of the present study is to evaluate the groundwater potential of the study area for groundwater development.

\section{PROBLEM DEFINITION}

There are difficulties encountered in developing stable and reliable water supplies for the rural Community. The basement complex terrain has posed significant constraints to economic and social development of many areas in Ondo State, Southwestern Nigeria. One of the towns located within the basement complex terrain of south-western Nigeria is Oba-Ile. It lacks reliable water supplies and surface water that people depend on is not constantly available which leads to scarcity of water in the area. As a result of this, groundwater is the only safe and permanent source of water in the area. The objective of this study is to conduct VLF-EM profiling across the study area in other to delineate bedrock fissures that are of hydro-geologic importance 


\section{International Advanced Research Journal in Science, Engineering and Technology}

Vol. 6, Issue 4, April 2019

The EM is a non-invasive geophysical method that has been widely used in the search for groundwater potential in the basement complex terrains of Nigeria [7][8]

\section{LOCATION OF THE STUDY}

Oba-Ile is located at the outskirt of the Akure metropolis, southwestern Nigeria; it lies within the basement complex terrain of Nigeria. It is bounded between longitudes $07^{\circ} 15^{\prime} 30^{\prime \prime}$ and $7^{\circ} 16^{\prime} 80^{\prime \prime} \mathrm{N}$, and latitude $05^{\circ} 14^{\prime} 45^{\prime \prime}$ and $05^{\circ} 15^{\prime} 90^{\prime \prime} \mathrm{E}$. Figure 1 shows the map of Ondo State indicating the study area and (Figure 2) shows the layout of sunshine Estate ObaIle Akure.

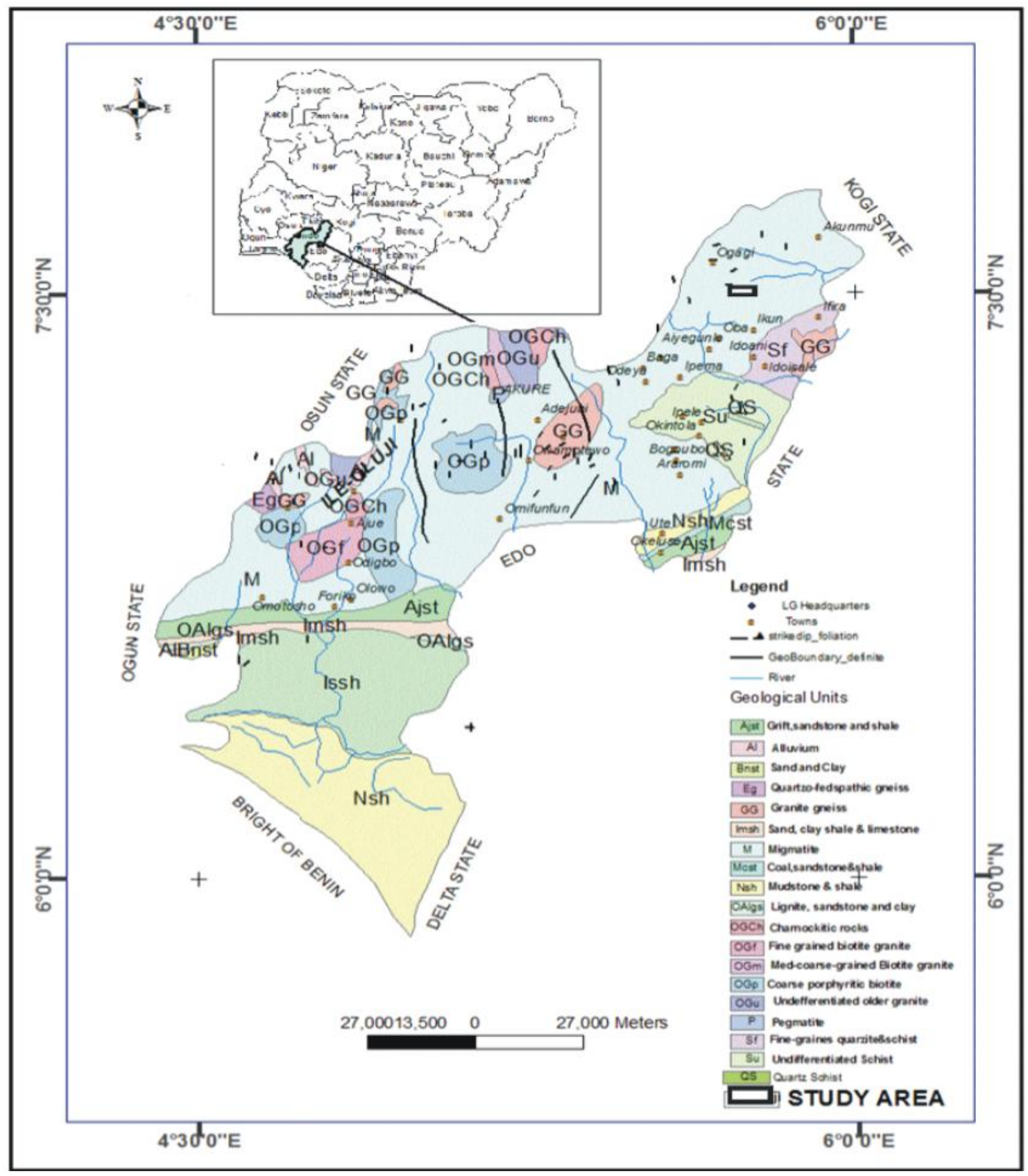

Figure 1: Geological map of Ondo state showing the study area (source: modified after GSN) 


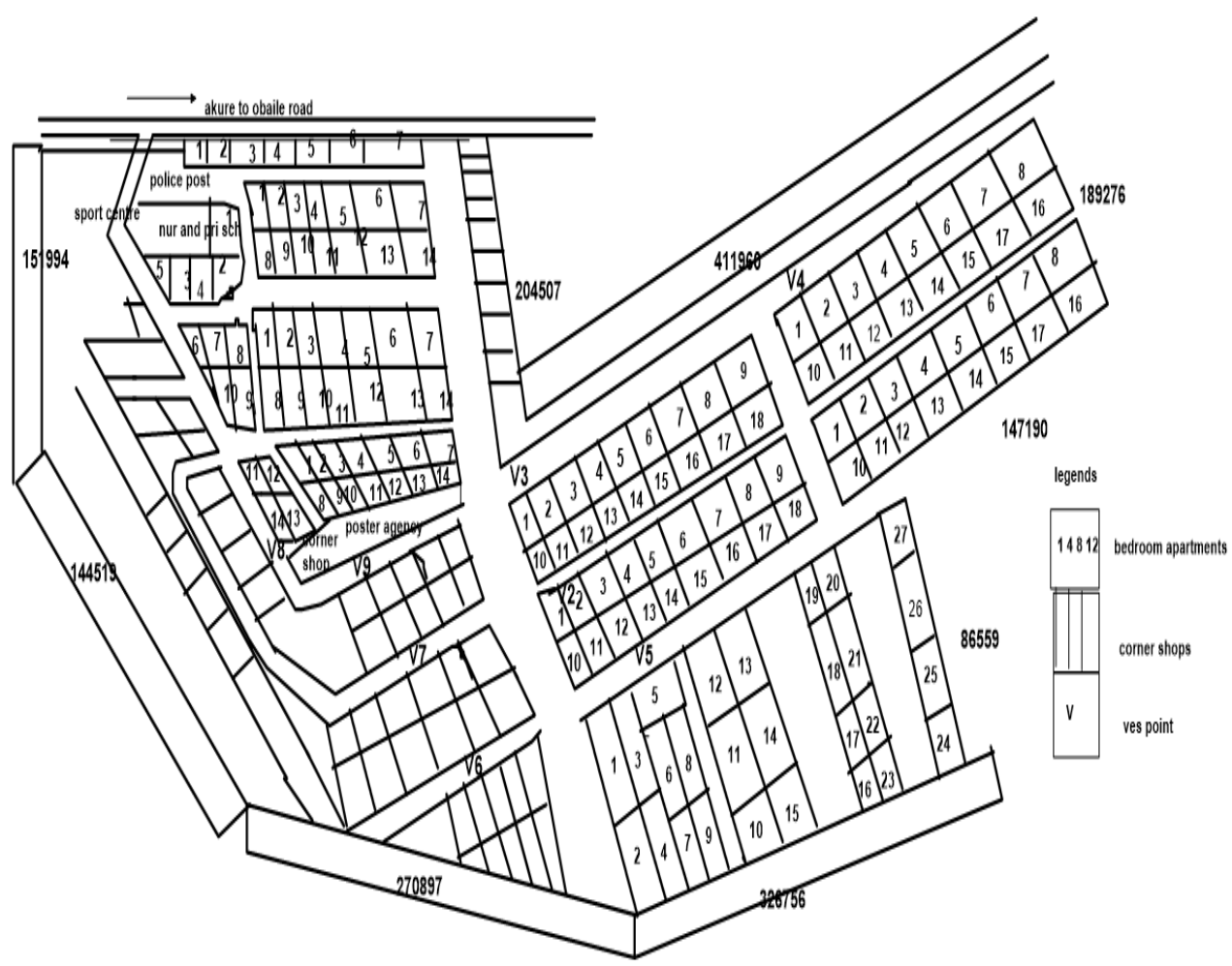

Figure 2: Map showing the layout of Sunshine Garden Estate Oba-Ile Akure

\section{GEOLOGY OF THE STUDY AREA}

The study area lies within the basement complex terrain, a south western Nigeria. It consists of early to late Proterozoic crystalline rocks of migmatites, quartzite and granites overlain by sequences of low grade porphyritic schist's. The basement complex covers about $50 \%$ of Nigeria and also extends to neighboring countries; Cameroon and Benin. The Migmatites Gneiss Complex (MGC) has been identified on the basement and it is said to be the most widespread of the major role units in the basement complex terrain of Nigeria. It is a heterogeneous assemblage which includes orthogneisses, Para gneisses, migmatite, and a series of ultrabasic and basic metamorphosed rocks [9]. The dominant rock types include garnet-biotite-schist and Gneiss-biotite-garnet, quartz schist and quartzite, variably undifferentiated hornblende-biotite-gneiss with intercalated amphibole, all belonging to the hornblende biotite gneiss and gneiss complex which are part of the older granite suite.

\section{MATERIALS AND METHODS}

The ABEM-WADI VLF Electromagnetic unit was used for collecting the data. A total of seven (7) traverses were established in W-E directions with each traverse length ranging from $90 \mathrm{~m}-450 \mathrm{~m}$ at the station intervals of $10 \mathrm{~m}$. The transmitter used for this study has a frequency range of 25-27.6KHZ with the direction at northwest to southeast (NW$\mathrm{SE})$. The ABEM-WADI VLF-EM equipment detects the percentage ratio between the horizontal and vertical components of the EM signal. Even when the primary field is horizontal; the normal reading on the ABEM-WADI VLF is set at zero (0) even when horizontally lying conductors are present.

The EM data are presented as profiles, although both Filtered Real and Raw Real components of the VLF-EM anomalies were considered in this study, the real components data being more diagnostic of linear structural features were processed for qualitative interpretation. The interpretation of VLF-EM is generally qualitative in nature. The VLFEM real components data were converted to filtered real data. Anomalous zones were revealed and a gross cauterization attached to the anomaly (e.g., thickening conductive overburden or steeply dipping conductor).VLF-EM method is an inductive Geophysical exploration technique used in mapping shallow subsurface structural geological features in which primary EM wave induces current flow.

The imaginary and real components data of the EM fields measured was subjected to filtering to increase the signal to noise ratio of the data set and assist in enhancing the anomaly signature [10]. The Fraser filter (Q) was computed using a filter operator as shown in the following relation: 


\section{International Advanced Research Journal in Science, Engineering and Technology}

Vol. 6, Issue 4, April 2019

$\mathrm{Q}=\left(\mathrm{Q}_{4}+\mathrm{Q}_{3}\right)-\left(\mathrm{Q}_{2}+\mathrm{Q}_{1}\right)$

Where Q is EM data and the subscripts are station positions.

The imaginary (quadrature) and raw real (in phase) components measured on the field were converted using an in-built filtering program provided in the ABEM WADI equipment as well as a software package (Karous and Hjeit filtering) into filtered real data in which anomaly inflections appear as peak positive anomalies and false VLF anomaly inflections appear as negative anomalies of the profiles.

\section{RESULT AND DISCUSSION}

\subsection{VLF anomaly profile}

Profiles (1-7) show the VLF-EM anomaly curves (filtered real and real component) along transverses TR1-TR7 (figure 3-9).

The linear structural features with positive filter real amplitude (high) in all the profiles reveals area with conductivity. The visual inspection of these anomaly curves allowed the identification of the top of linear features as points of coincident of cross over and positive peaks of the filtered real and real anomaly curves. The high positive peak filtered real amplitudes show the area affected by suspected geologic structural features. However, these features are suspected to be conductive.
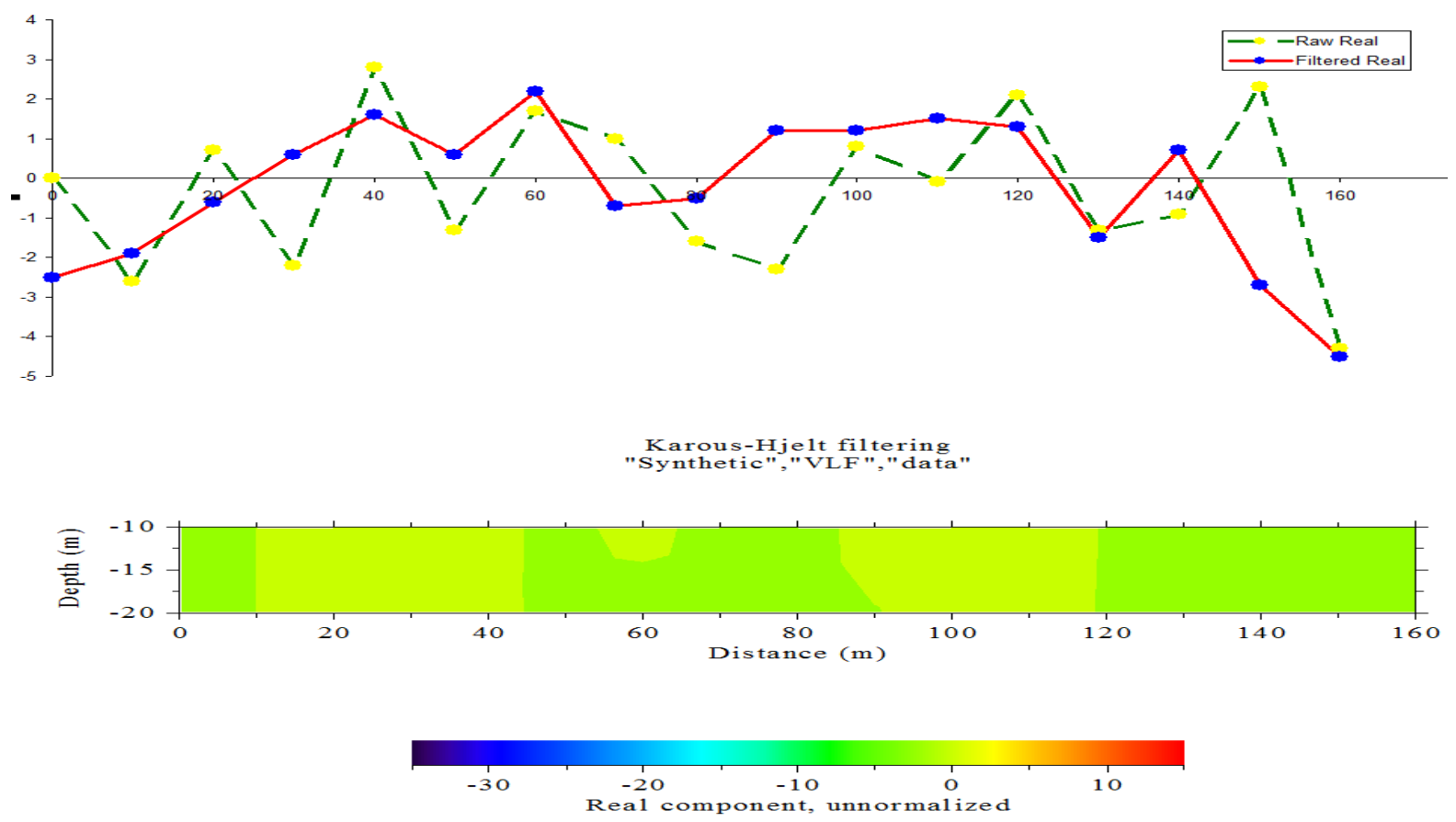

Figure 3: VLF-EM profile along traverse 1and Karous and Hjeit pseudo section of the inverted VLF-EM real component of the profile.

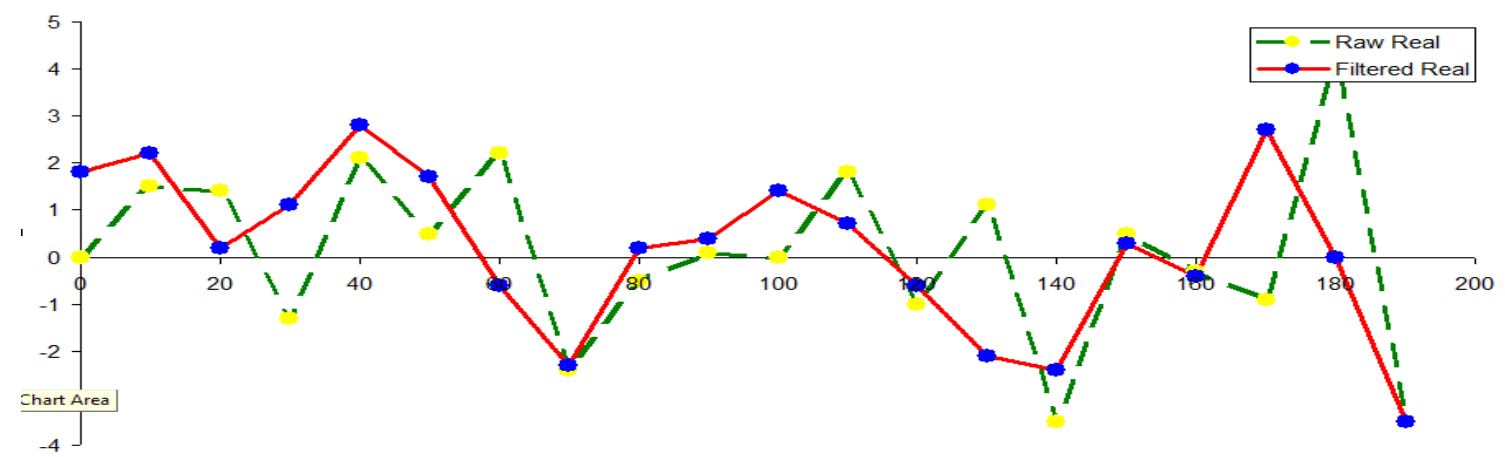




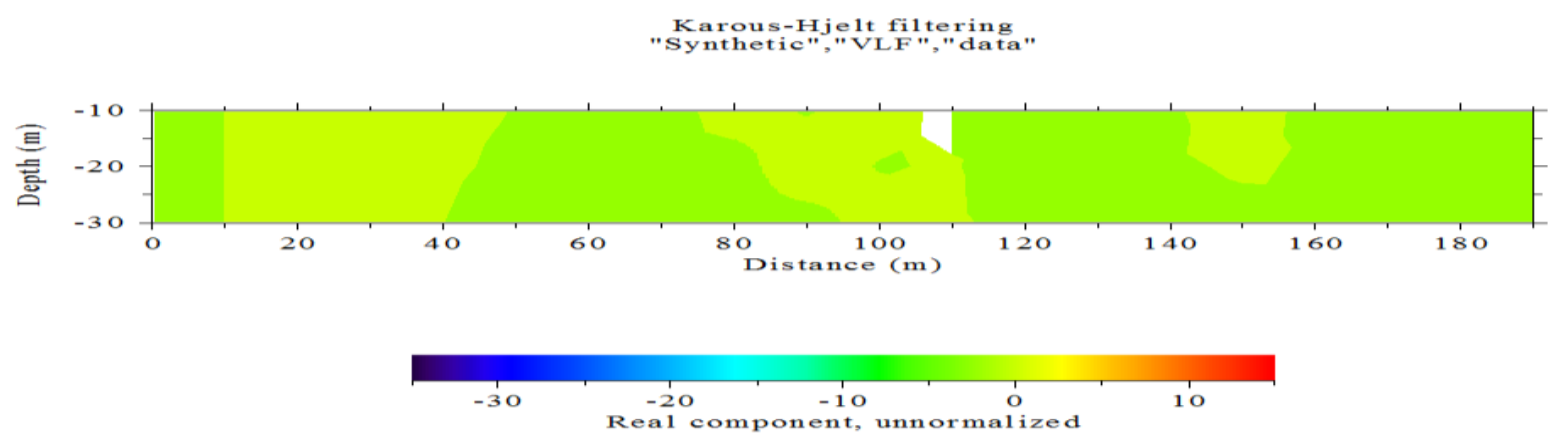

Figure 4: VLF-EM profile along traverse 2 and Karous and Hjeit pseudo section of the inverted VLF-EM real component of the profile.
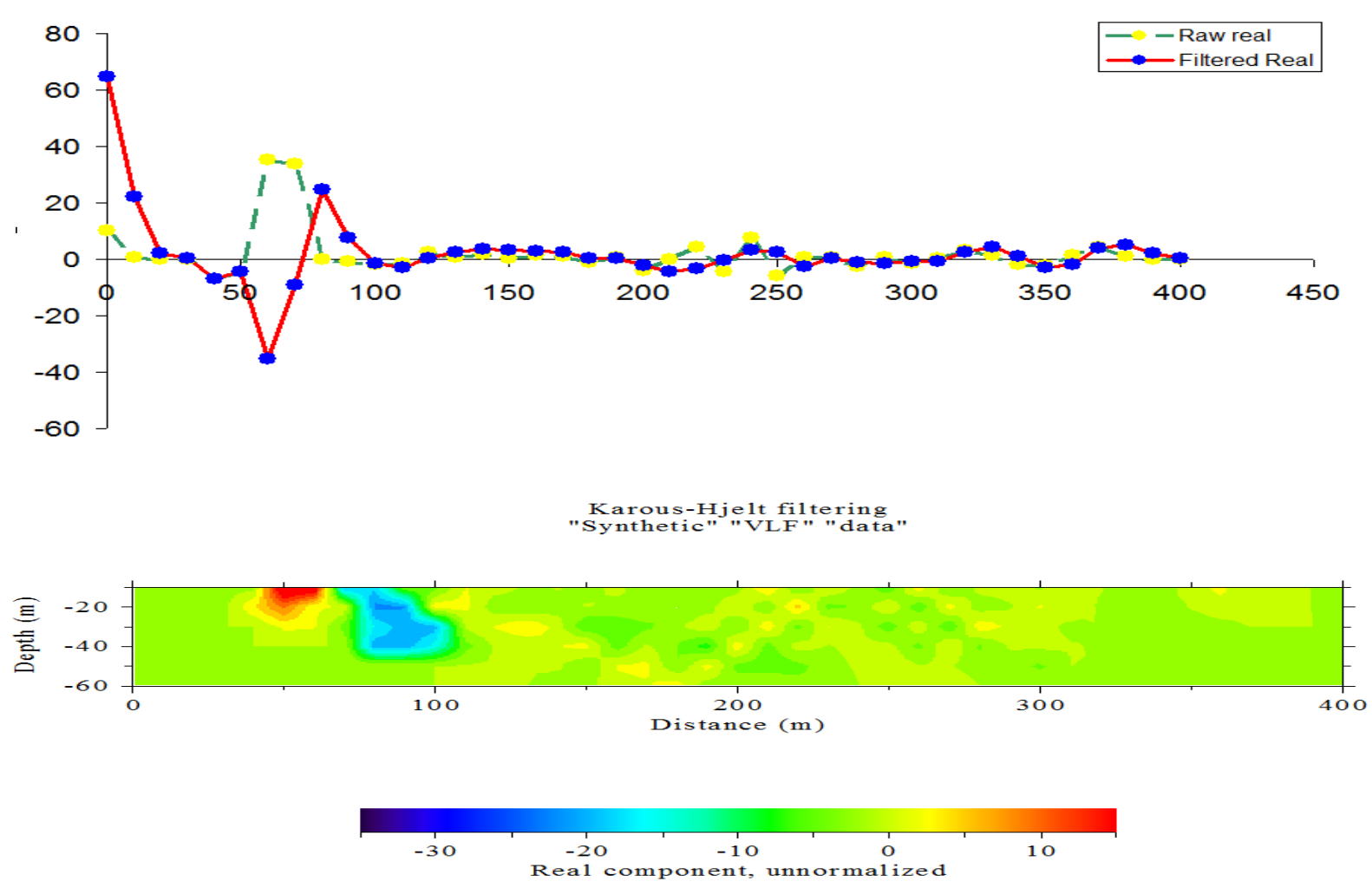

Figure 5: VLF-EM profile along traverse 3 and Karous and Hjeit pseudo section of the inverted VLF-EM real component of the profile.

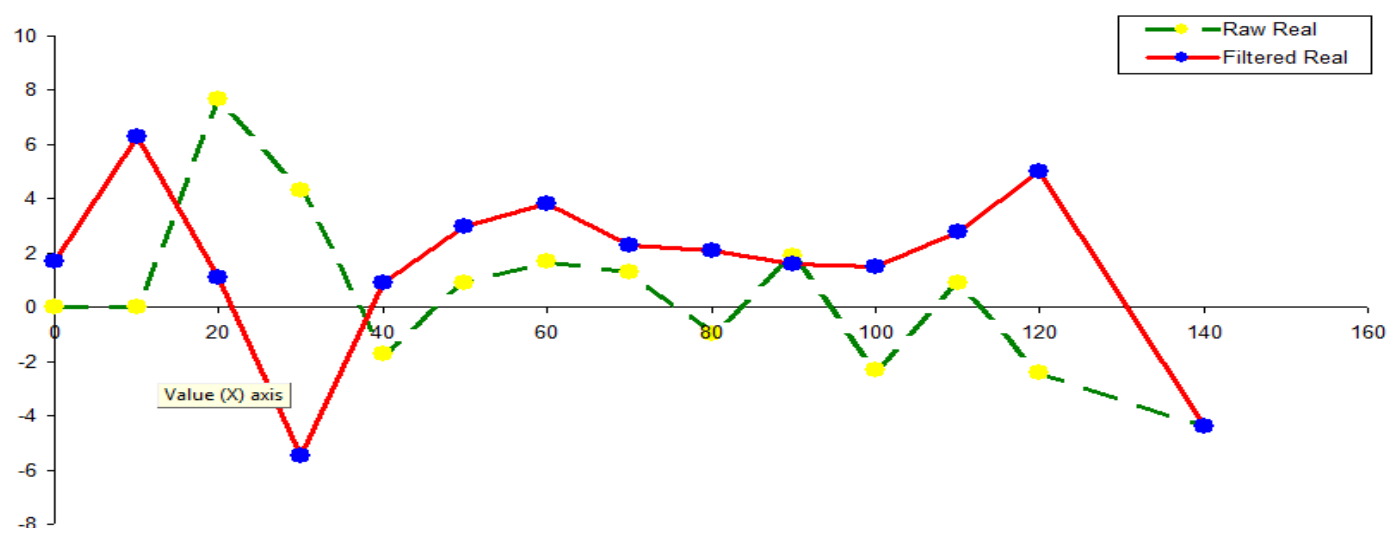


Vol. 6, Issue 4, April 2019
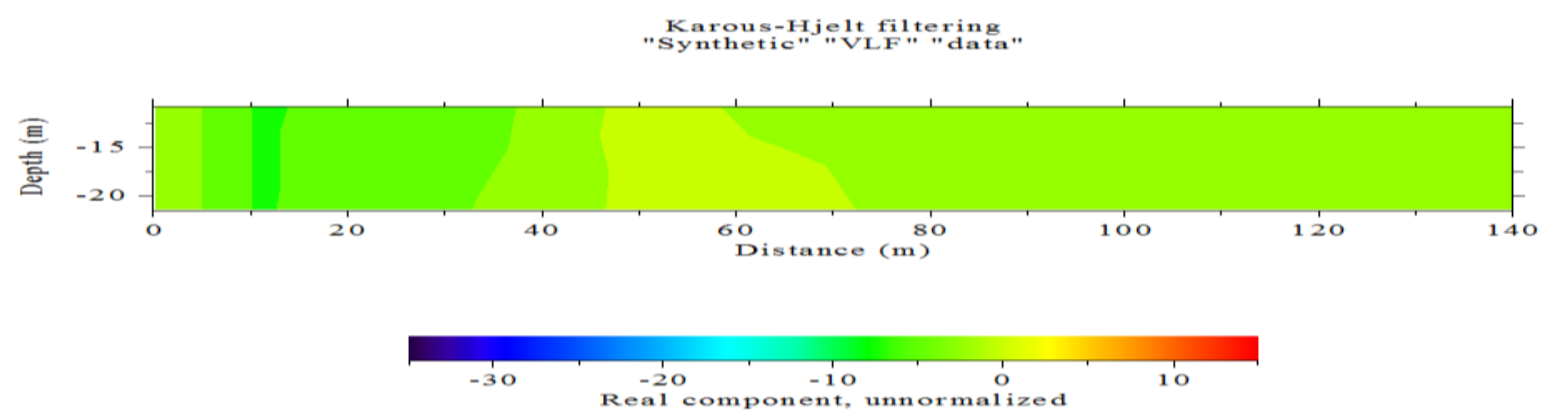

Figure 6: VLF-EM profile along traverse 4 and Karous and Hjeit pseudo section of the inverted VLF-EM real component of the profile
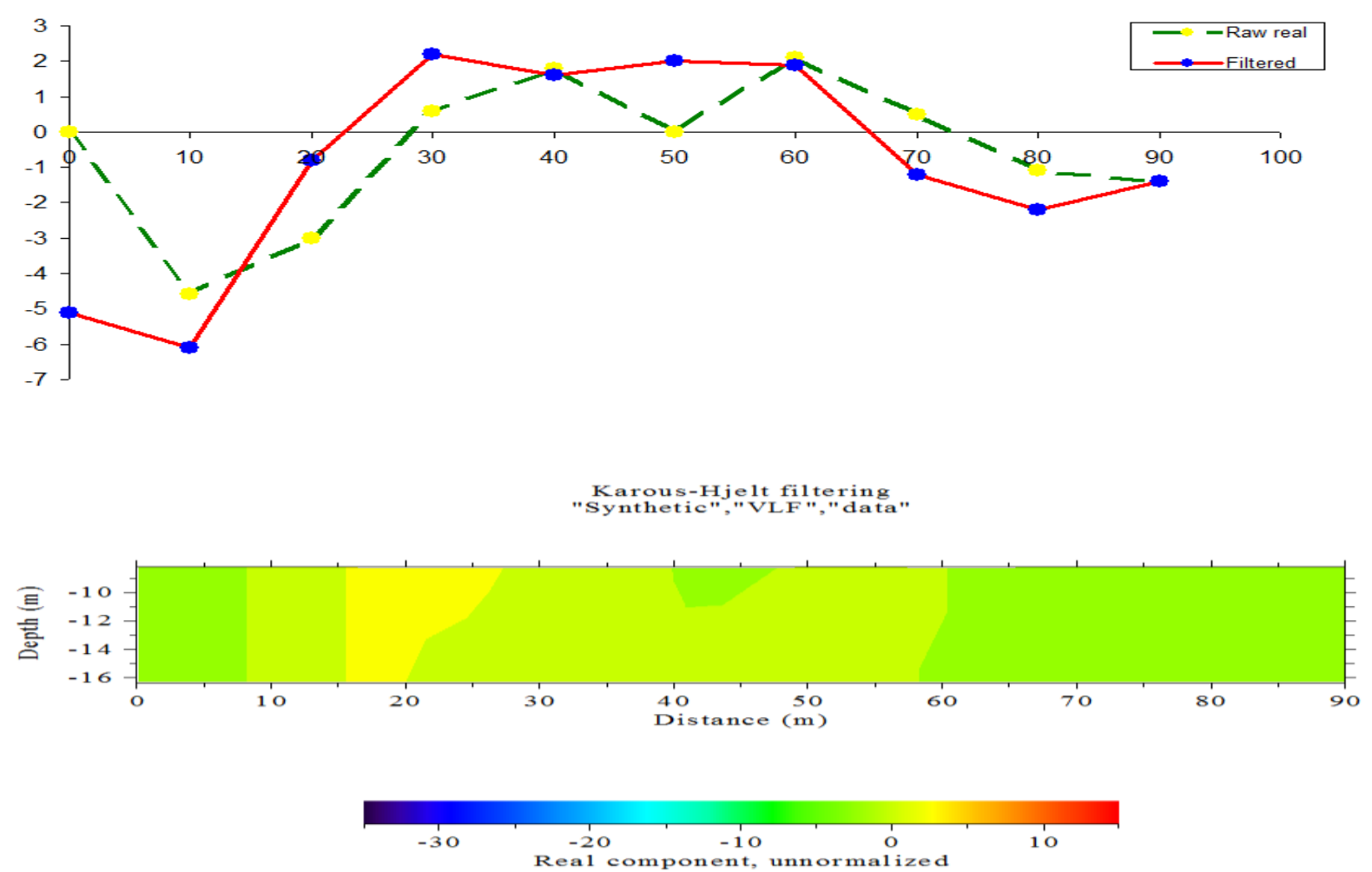

Figure 7: VLF-EM profile along traverse 5 and Karous and Hjeit pseudo section of the inverted VLF-EM real component of the profile.

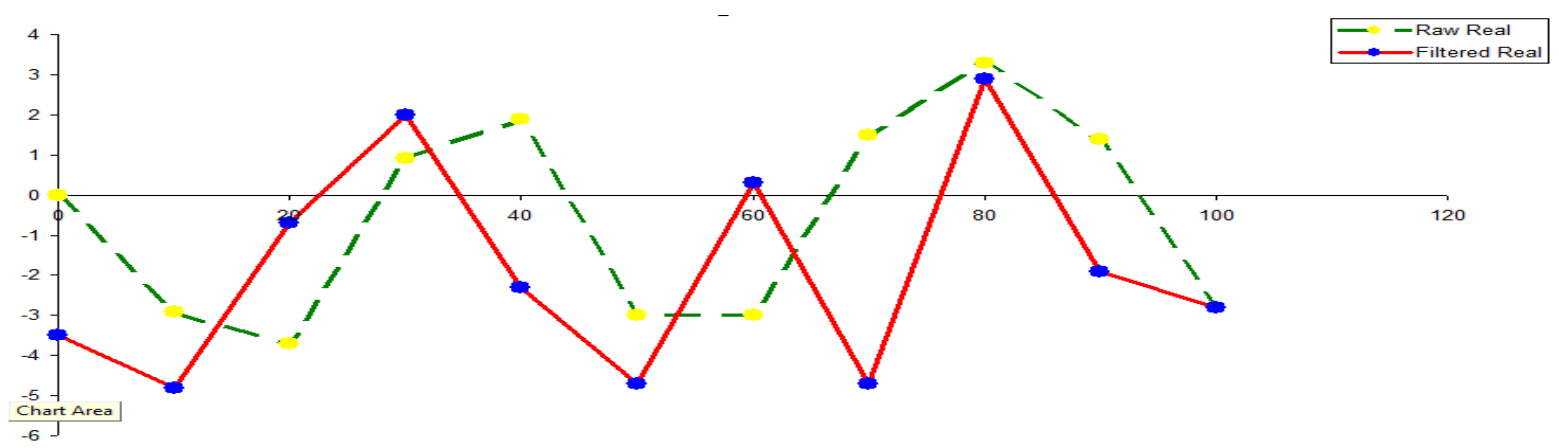


Vol. 6, Issue 4, April 2019

Karous-Hjelt filtering
"Synthetic","VLF","data"
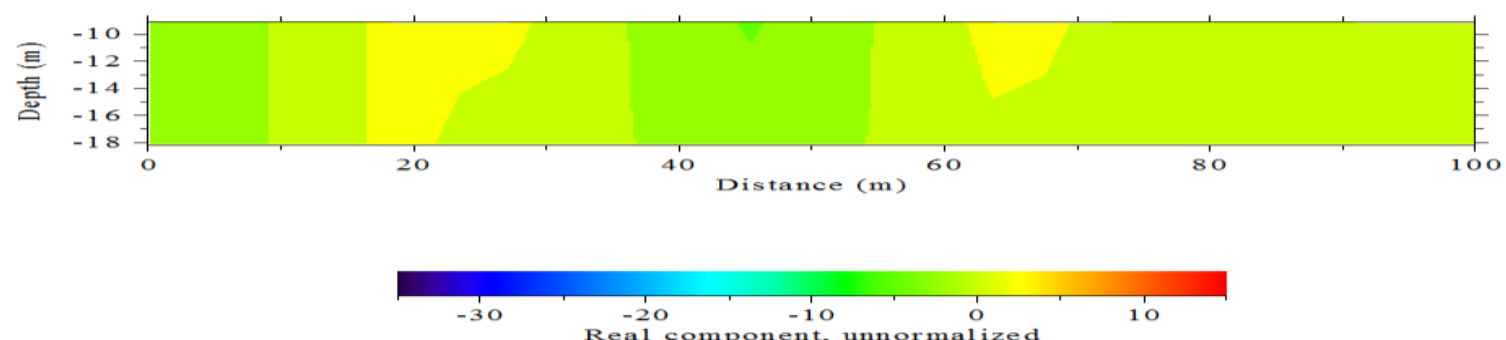

Figure 8: VLF-EM profile along traverse 6 and Karous and Hjeit pseudo section of the inverted VLF-EM real component of the profile

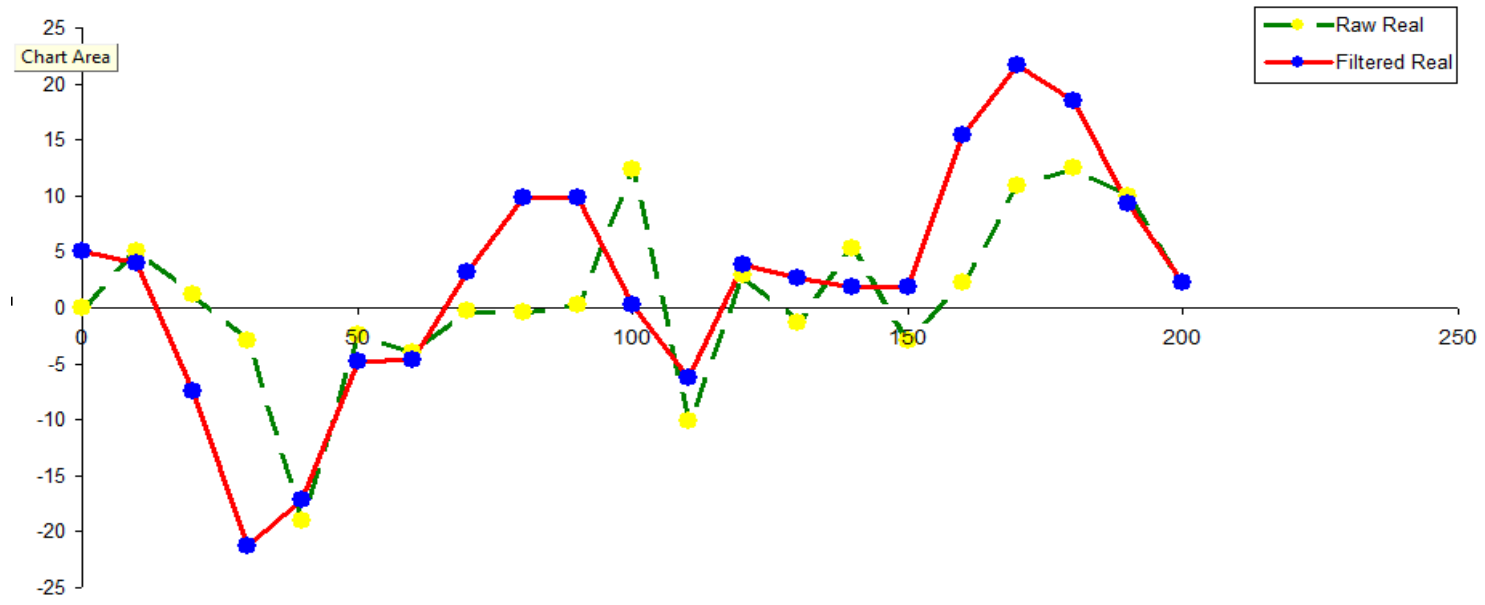

Karous-Hjelt filtering "Synthetic","VLF","data"
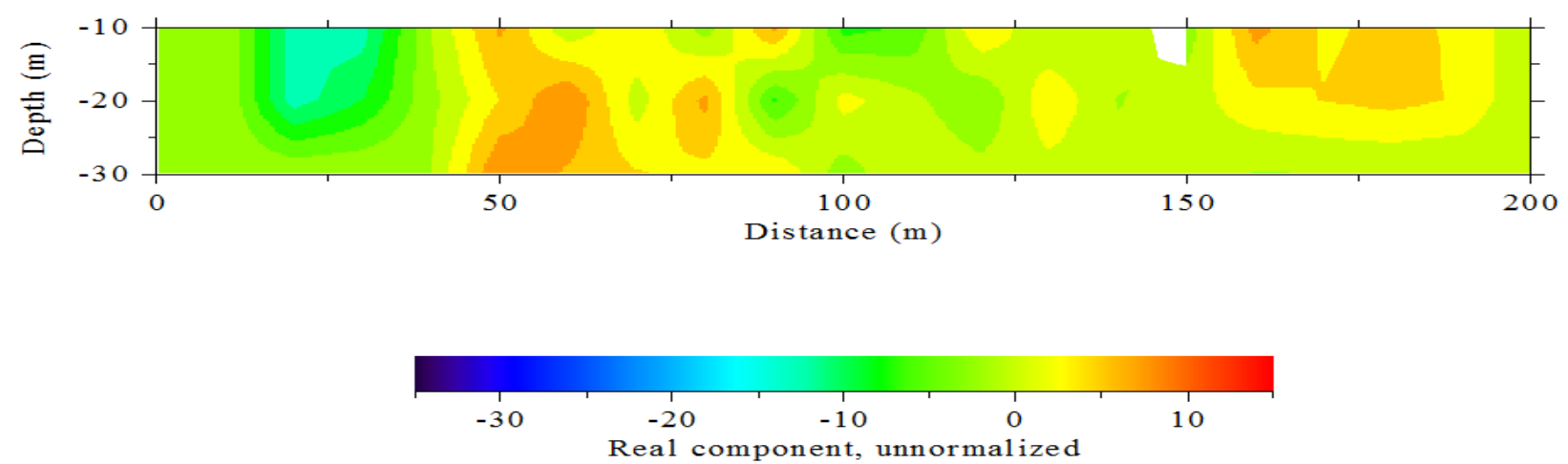

Figure 9: VLF-EM profile along traverse 7 and Karous and Hjeit pseudo section of the inverted VLF-EM real component of the profile. 


\section{International Advanced Research Journal in Science, Engineering and Technology}

Vol. 6, Issue 4, April 2019

a. Interpretation of the VLF-EM Profiles

Interpretation was done by considering areas with high amplitude signals suspected to be diagnostic of fractured or weathered zones. The double plots of the filtered and raw real imaginary components enable better identification of the top of linear features. Figure. 3-9 shows typical EM profiles and pseudo sections from the study area. The result shows that EM anomalies vary significantly; some of the anomaly peaks are sharp and narrow, while others are broad with varying width extent.

The values of the filtered imaginary vary from -35.1 to 64.8 while that of the raw real ranges from -19 to 35.1 across the study area. The profiles for the EM sections contain small filtered anomaly in the imaginary part and significant maxima in the real part. Zones with peak positive filtered real anomalies are considered priority areas for groundwater development in the study area since its correlates with zones of high conductivity which is a characteristic of water filled faults or fractures [11][12]

\section{CONCLUSIONS}

The electromagnetic profiling in the Sunshine Garden Estate, Oba-Ile has contributed to a better understanding of the basement complex terrain of Southwestern Nigeria. Sites with high electromagnetic anomaly (high positive filtered real anomaly) as shown in the EM profile can be expected to be aquifers, implying locations suitable for the groundwater development in the study area.

\section{REFERENCES}

[1]. Beeson, S. and Jones, C. 1988. "The Combined EMT/VES Geophysical Method for Siting Boreholes". Journal Groundwater. $26(1)$ : 54-63.

[2]. Hazel, J., Cratchley, C.R., and Preston, A.M. 1988. "The Location of Aquifer in Crystalline Rocks and Alluvium in Northern Nigeria using Combined Electromagnetic and Resistivity Techniques". Quarterly Jour. Enh. Geol. 21:159-175.

[3]. Olayinka (1990). "Electromagnetic Profiling for Groundwater in Precambrian Basement Complex Areas of Nigeria". Nordic Hydrol. pp. 205 216

[4]. Olayinka, A.I, Amidu, S.A., and Oladunjoye, M.A. 2004. "Use of Electromagnetic Profiling and Resistivity Sounding for Groundwater Exploration in the Crystalline Basement Area of Igbeti, Southwestern Nigeria”. Global Journal of Geological sci.2 (2):243-253

[5]. Palacky, G.J., Ritsema, I.L., and De Jong, S.J. 1981. "Electromagnetic Prospecting for Groundwater in Precambrian Terrains in the Republic of Upper Volter". Geophy. Prospect. 29:932-955

[6]. Bernard, J. and P. Villa, 1991. Groundwater exploration in fissured media with electrical and VLF methods. Geoexploration, 27: 81-91

[7]. Olayinka AI, Olorunfemi MO (1992). Determination of geoelectrical characteristics in Okene area and implication for Borehole sitting. J. Mining Geol. 28(2):403-412.

[8]. Omosuyi, G.O., Ojo J.S. and Enikanselu, P.A. 2003. "Geophysical Investigation for Groundwater around Obanla - Obakekere in Akure Area within the Basement complex of South-Western Nigeria”. Journal of Mining and Geology. 39(2):109-116.

[9]. Rahaman, M. A. 1988. Recent advances in the study of Basement Complex of Nigeria, Geological Survey of Nigeria,

[10]. Fraser, D. C. 1969. Contouring of VLF-EM data. Geophysics, Vol. 34, pp. $958-967$

[11]. Alvin, K.B., Kelly, L.P., and Melissa, A.S. 1997. "Mapping Groundwater Contamination using DC Resisting and VLF Geophysical Methods A Case Study". Journal of Society of Exploration Geophysicist. 62(1): $80-86$

[12]. White, C.C., Huston, J.F.T., and Baker, R.D. 1988. "The Victoria Province Drought Relief Project, 1. Geophysical Sitting of Boreholes". Groundwater. 26(3). 